\title{
液體の粘度に對する電場の影響に就で I.
}

(昭和十八年二月十九日受領)

木 村 修

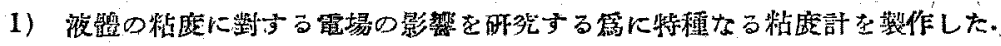

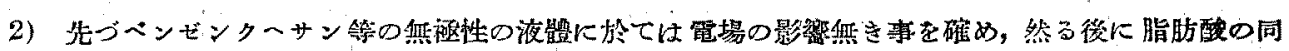

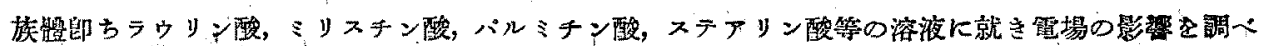

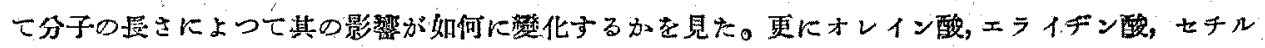
アルンール及びェチルせルローズ禁に就てを测定した.

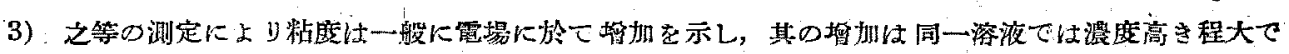
あり, 更に

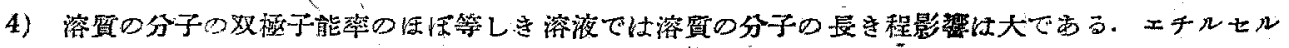

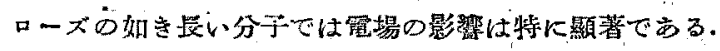

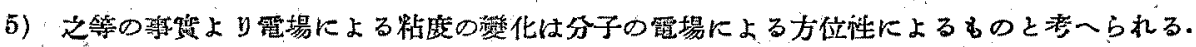

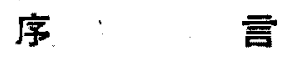

球狀に非らざる分子又は膠質粒子が流動狀態にある時郎ち速度勾配のある場所に圆かれる時は最

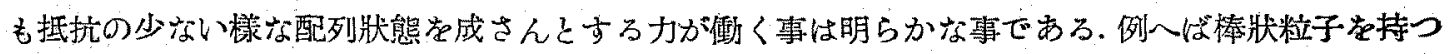

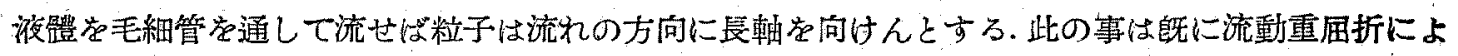

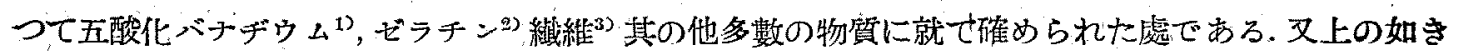

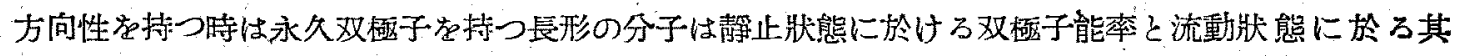
れとは值在異にする等である。此の事も又筫驗的に確められてる、る

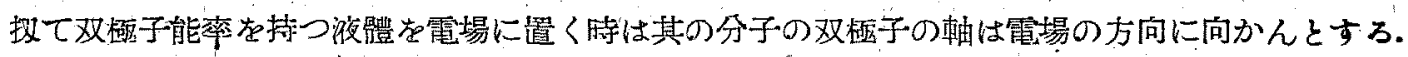
從つて分子形狀の長形にして奴極子能率を持つ泼體を流れの方向に直角に電場をかりて流す時は流 れの狀態は電場によつて變化來し，從つて其の粘度に影響存值へろ事は容易に考入得る處である.

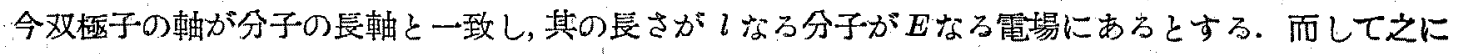

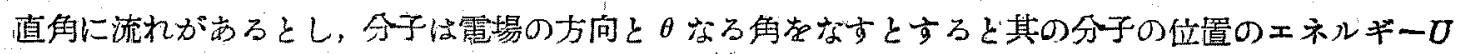
は次式によつて與へられる。

$$
U=-(\mu E \cos \theta+l F \sin \theta)
$$

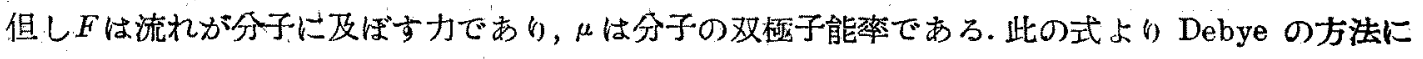
從つて流動のある場合の一個分子の平均能率を計算し得る譯であるが，Fは一般に不明であるから，

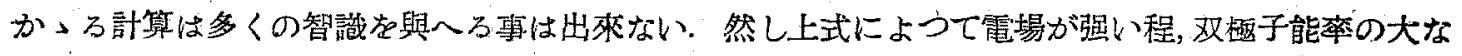

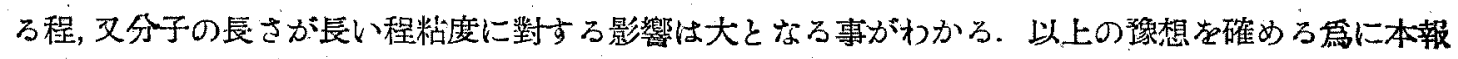
告に於ては双極子能率の殆ど一定にして分子の長さの異なる數種の 長形分子郎ち脂肪酸の 同族髐た ろラウリン酸, ミリスチン酸, パルミチン酸, ステフリン酸のベンぜン溶液に就て粘度に對する電場の

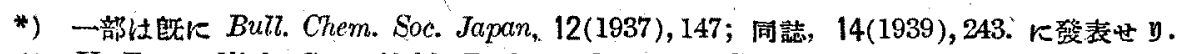

1) H. Freundlich, Stapelfeld, Zocher: Z. physik. Chem. 114(1924), 161.

2) E. Krüger: 同_F, 109(1924), 438.

3) 金丸及び共同研焱者: 工業化學䧴誌, 45(1942), 478.

4) V. Marinin, V. Tsvetkov: Aeta Physicochimica U.R.S.S., 11(1939), 837. 
影響を研究し，更にオレイン酸，エライヂン酸，セチルフルコホル，エチルセルローズ等のヘンゼン 溶液或はへクサン溶没に就ても测定を行つた. 溶媒たるへンゼン及びヘクサンは電場に於て其の粘度 に何等の變化なき事は踭め確めた。

投て粘度に對する電場の影響に就て占來可なり研究されてるる.而して之等は主として一成分系に 就てのみ行はれてるるのであるが，その結果は未だ定性的範圍に止まり，或る人は電場の影響は無い と云ひ，或る人は影響があると主張し，互に矛盾せる結果が多い. 更に溶液に就ては殆ど研究されたる 結果が無く.僅かに Passynski ${ }^{6}$ がゴムの溶液に就て研究し, Björnstahl 及びSnellman ${ }^{7}$ がロイド

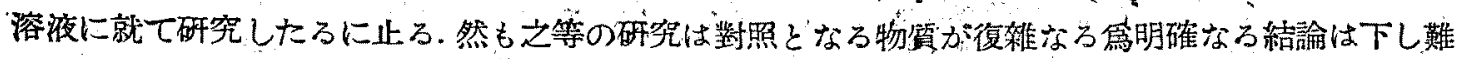
い.此處に於て著者は先きに述べた理由の下に簡單なる物質に就いて貫驗して，先づ電場によつて粘

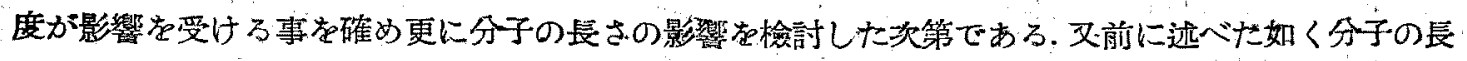
さが一定なるも双極子能率の大小によつても電場の影響は異る筈である.之に就ては一成分系に就て

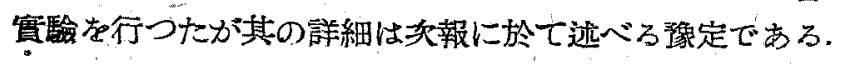

\section{實 驗 装 置}

實驗方法は流動法を用ひオストワルド氏型の粘度計の 毛細管の部分に流れた直角に電場をかけ得

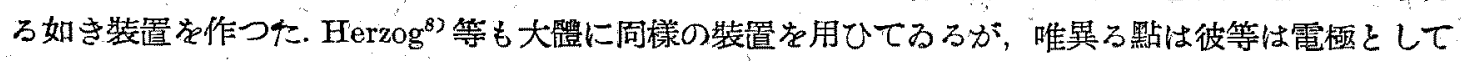

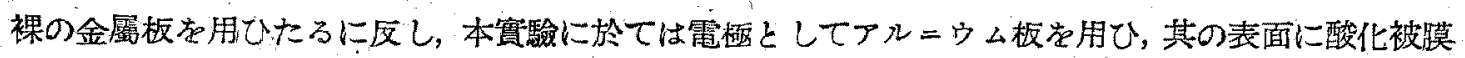
を作つて電氣的に不導體とした點にめる.かっる電極を用ひた理由は裸の金屬を電極に用ふる場合

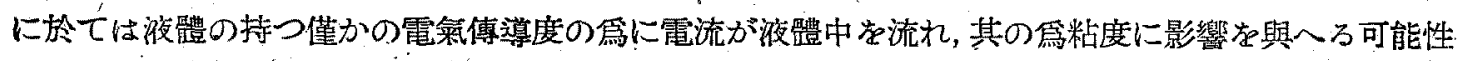
があるからである.この點に就ては Sokolow ${ }^{92}$ 等及び Andrade ${ }^{10)}$ 等の研究する處であつて，液體中 に電流が流れる時は粘度は大き影響定受けると云はれてるる.本裝置に於ける如き電極る用ふる場 合汢傳尊度の影響㭱無視出來ると考へられる。

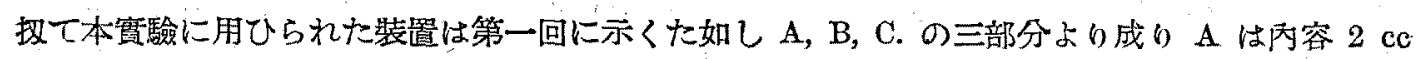

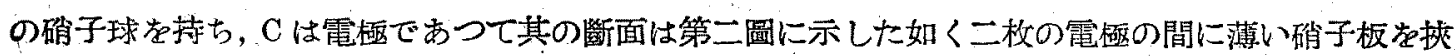
み, 中間に液體の流れる幅 $0.3 \mathrm{~cm}$ 厚さ $0.02 \mathrm{~cm}$ の矩形の斷面を持つ毛細管を作る确子板々電極とは デュチンスキーセメントで附着する.毛細管の長さは $6 \mathrm{~cm}$ である. 測定方法はオストワルド氏粘度 計と全く同様である. 測定中溫度の一定なる事必必要とする事は勿論であるが，之は空氣恒溫槽中に て測定する事によつて目的を達した，溫度の變動は $0.1 \mathrm{C}^{\circ}$ 以下であつた.

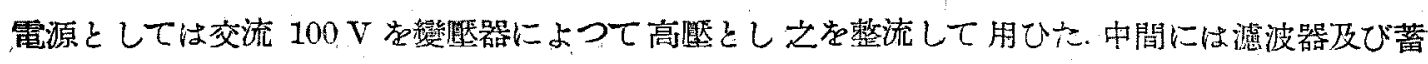

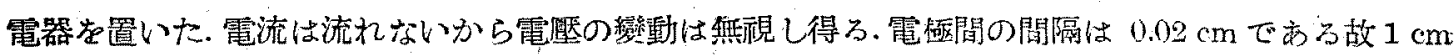
あたりの電壓の勾配ば酸化被膜の厚さを然視すれば惯際にかけられた電覧を50倍する事によつて得 られろ:

5) Krönig: Wied. Ann., 52(1885), 618. Duff: Phys. Review, (1896), 23; Quincke: Wied. Ann,, 62(1897), 7; Lenard: Ann. Physik, (4) 61 (1920), 715; Herzog and others: Naturwiss., 21(1933), 622; Physik. Z., 35(1934), 466; Alock: Physics, 7(1936), 126. Ejörnstahl: Physics, 6(1935), 257. Dobinski, Physiz. Z., 14(1935), 509. Sokolow, Sosinski: Acta Phisinachimica U.R.S.S. 5(1936). 433. 691.

6) A. Passynski: Kolloid-Z, 70(1935), 180.

7) Y. Björnstahl and Snellman: 同誌, $78(1937), 258$.

8) Herzog. Kudar, Paersch: Naturwiss., 21(1933), 622.

9) Sokolow, Sosinski: Acta Physicochimica U.R.S.S. 5(1935), 433, vil.

10) Andrade: Nature, 143(1939), 26. 


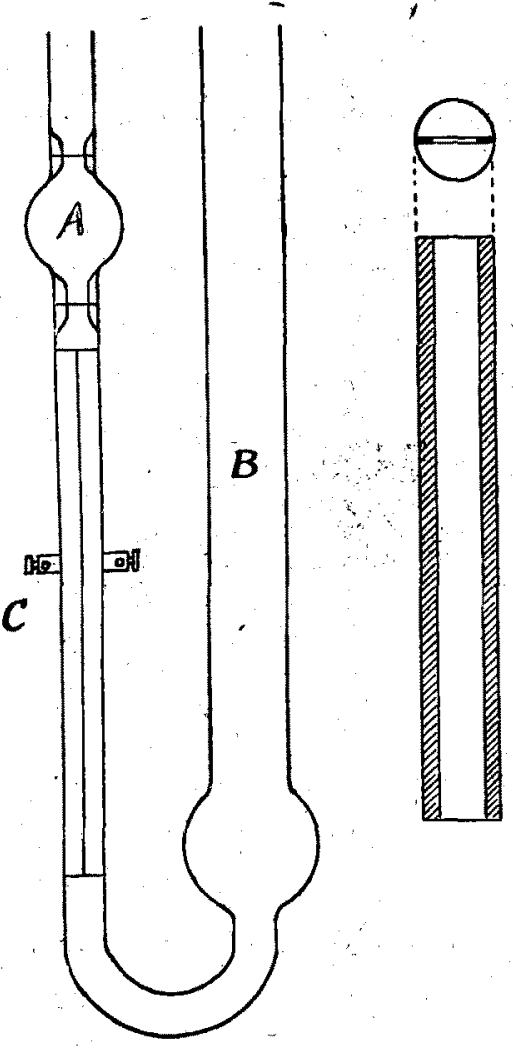

第 1 圆 留 驗 装 置

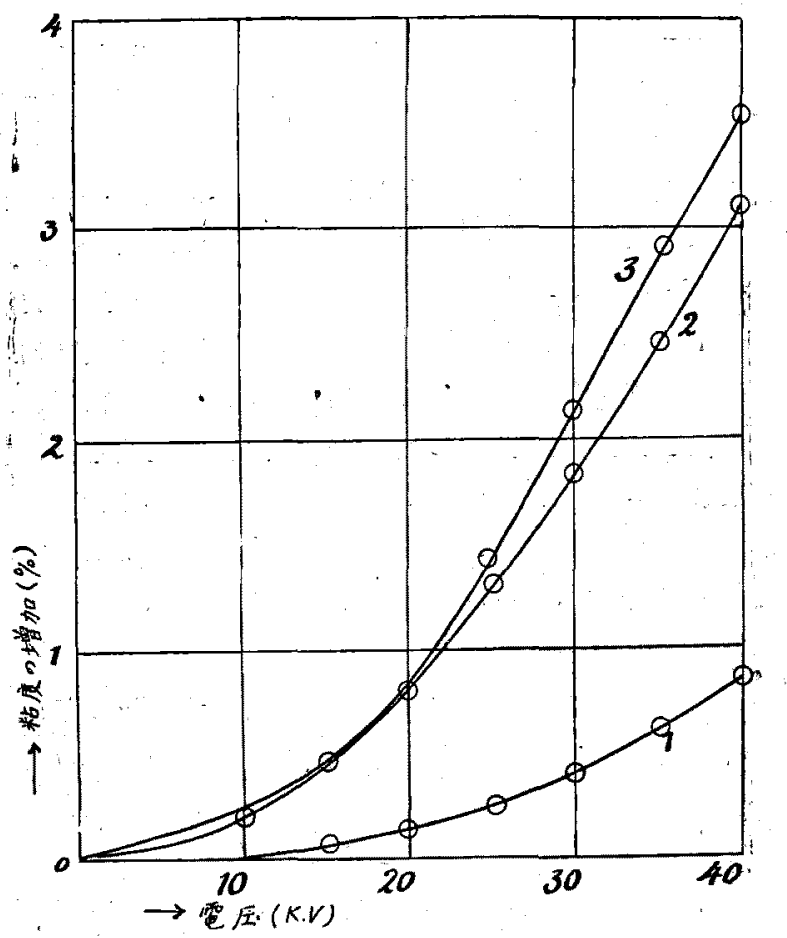

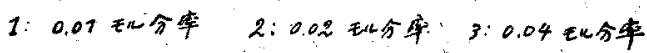

第 3 圈 ミリスチン酸(溶偨べンゼン)

资に矩形の斷面を持つ毛細管中の液體の流れ心 は Rowell 及び Finlayson ${ }^{11)}$ に上つて次の如く 計算された。

$$
Q=\frac{4}{3} \cdot \frac{P}{\eta} b h^{3}\left(1-x \cdot \frac{h}{b}\right) t
$$

但し $x=\frac{192}{\pi^{5}} \cdot \sum_{n=1}^{n=\infty}\left(\frac{1}{n^{5}} \cdot \tanh \frac{\pi n l}{2 h}\right), n$ は奇數 本式に於てQは $t$ 秒間に流れた推體の量.クは粘 度, $b$ と $九$ 矩形の二邊，Pは四力差, $x$ は $b \varepsilon h$

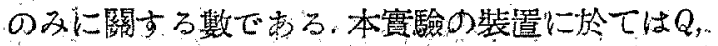
$P, b$ 及びんは一定なる故淮體の比重を一定とす れば

$$
\eta \infty t
$$

なる關係を得る。之はオストワルド氏の粘度計に

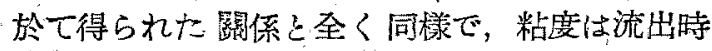
間によつて直ちに計算し得る。

\section{實驗結果及考察}

實驗に用ひたベンゼン及びへクザンはメ゙ルク

11) G. Barr: Engineering, 126(1928), 249, 385. "A Monograph of Viscometry", (1931), 145. 


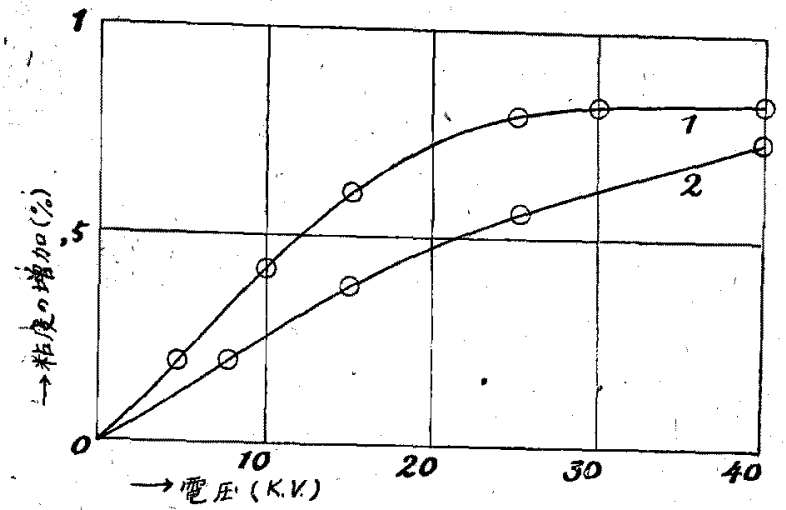

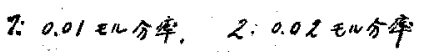

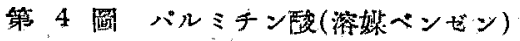

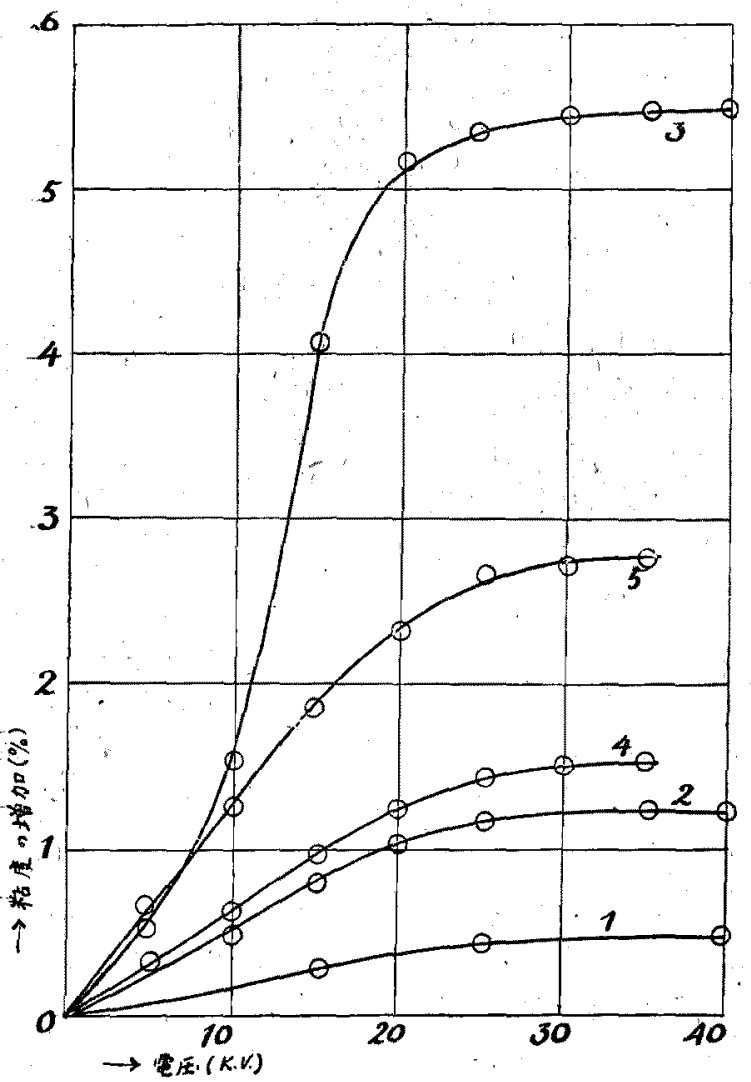

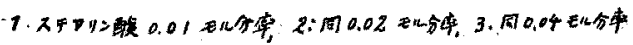

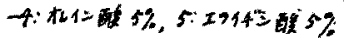

第 5 图 ステアリン酸，オレイン酸、ェラ イヂン酸(溶媒ベンゼン)

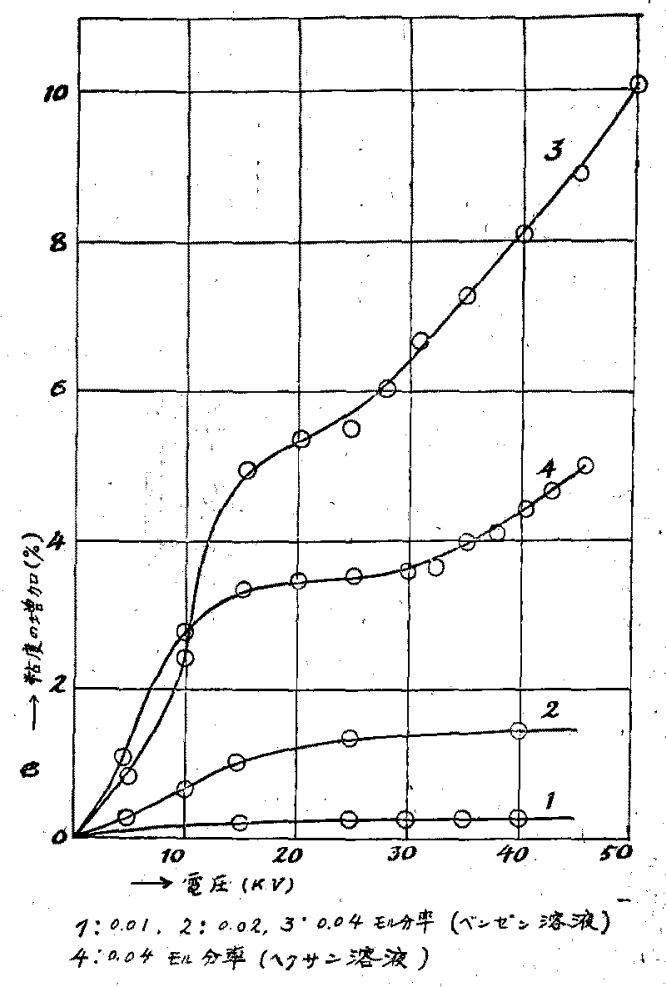

第け四 七テルアルコール(溶媒ベンゼン

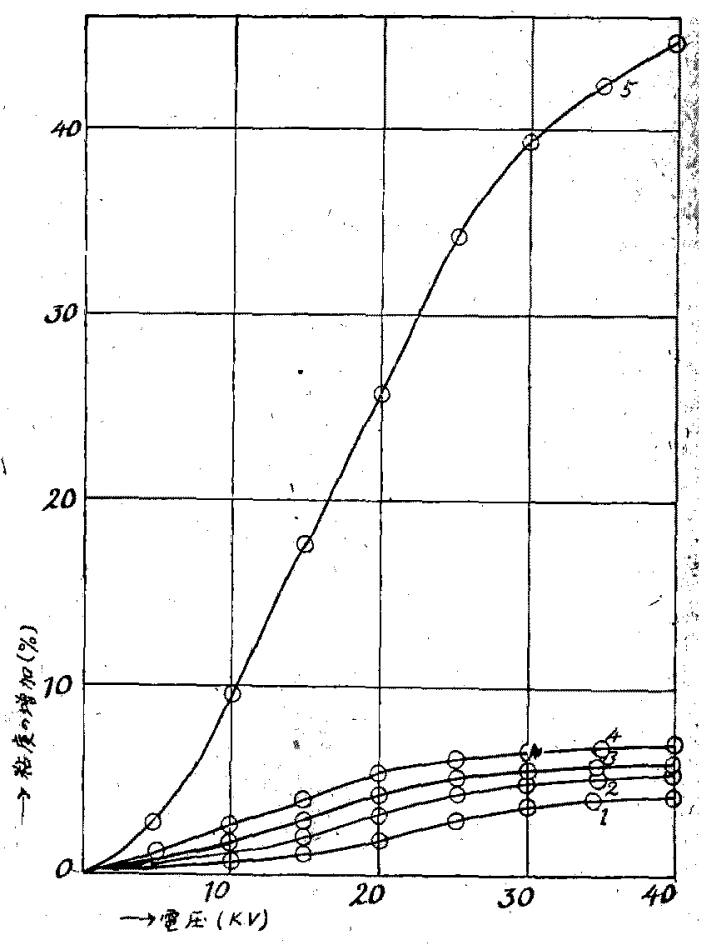

$1: 0.01 \% \quad 2: 0.025 \% . \quad 3: 0.05 \%, 4: 0.1 \%, 5: 0.25 \%$

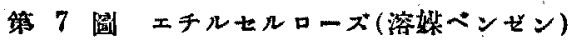




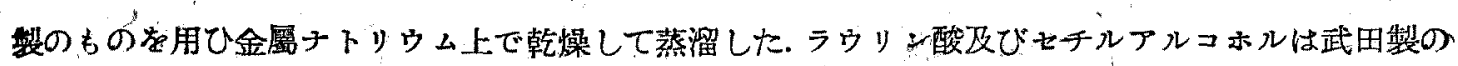
試藥を用ひ、ステフリン酸, ペルミチン酸, ミリスチシ酸,オレイン酸,エライヂン酸等はメルク製のも のを其の笽用ひ，エチルセルローズは方販品を用ひた。溫度の單位としては土チルセルローズ以外は

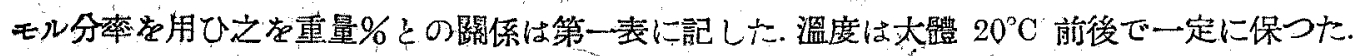

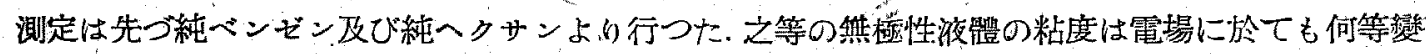
化しなかつた. 之は從來の實驗結果と一致する所のものである. 次に上記の如き溶液に就て䔈驗を行 つた. 之等の溶液に於ては電場をかけると粘度は一般に增加を示ず，測定の再現性を確める雹に電場 孝名けた場合とかけ場合とに就て流出時間を交互に測定したるに再現性々充分である事を知つた.

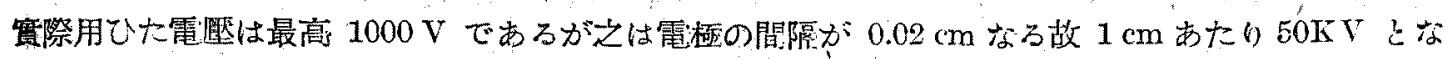

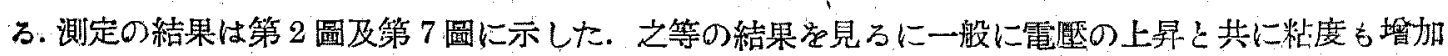

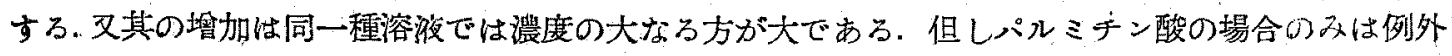

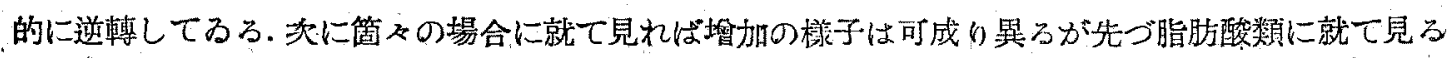

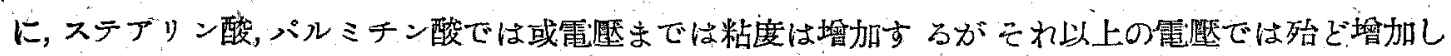
ない.ミリスチン酸,ラウリン酸では望驗の範圍に於て其の樣な傾向は現はれ小かつた. パルミチン酸

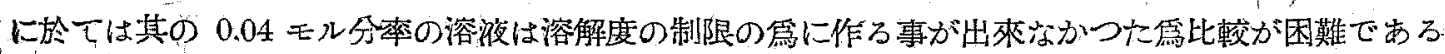

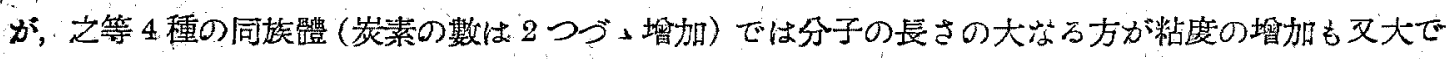
ある.次にオレイン酸及びェライヂン酸は同位踣で，炭素の數ばステフリンと同數の不飽和脂肪酸で 其等の粘度增加は定性的にステフリン酸のそれによく似てるるが, 量的には小である. 一方Langmuir

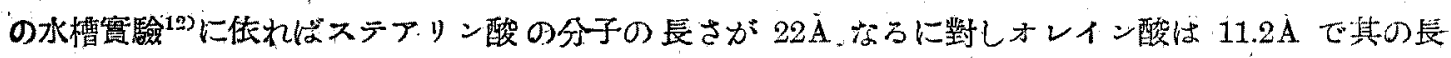
さが約牛分であると云ふ結果学得てるるが，之等は前述の脂肪酸の場合に於ける分子の長きもの程

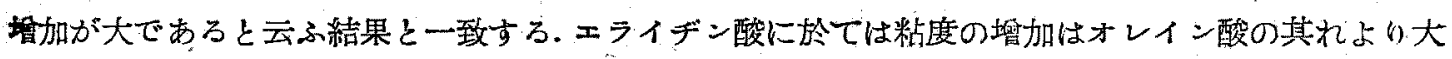
であるが此れも分子構造と何等かの關係があると思はれろが今の所明瞭でない. 份之等の脂肪酸の双 極子能率は總べて殆ぞ同一で大體 $1.8 \times 10^{-18}$ (靜電單位) である.次にもチルアルニホれに於ては粘

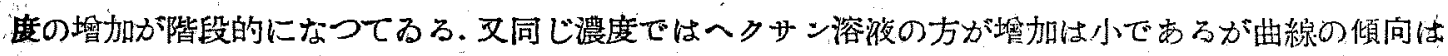
非常によく似てるる.

タ大にェチルセルローズは上迅の物質に比すれれば分子の長さの枯度に大なるものであるが, 其の電場

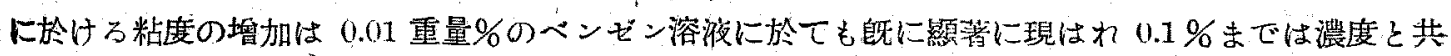
に粘度の燴加は大となるが $0.25 \%$ に於ては飛躍的に大となる.かくの如き現象の原因は $0.1 \%$ 以下

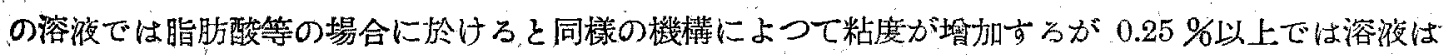

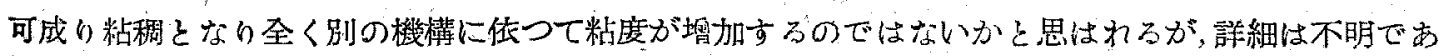
る.併しェチルセルローズの如き長形分子化合物では０.01％の如き稀薄溶液で既に可なり大きな影

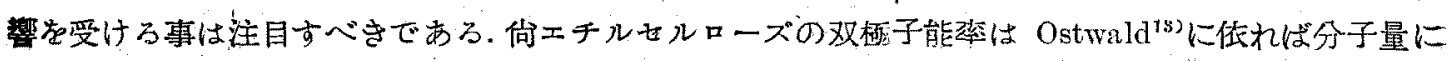

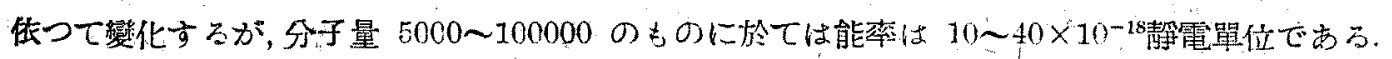

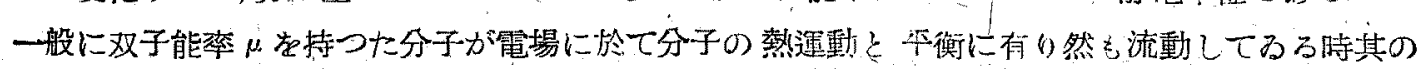

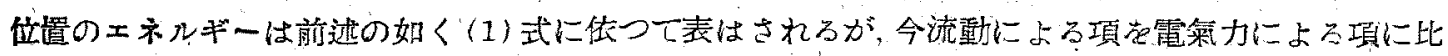

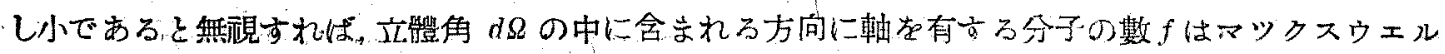
一ボルツマンの分布法則に依つて

$$
f=A e^{-\mu E / k T \cdot \cos a} d \Omega
$$

13) Wa, Ostwald, R.Riedel: KolloiuZ. 70(1935),75.

12) Langmuir: J. Am. Chem. Soc., 39(191, 1848. 


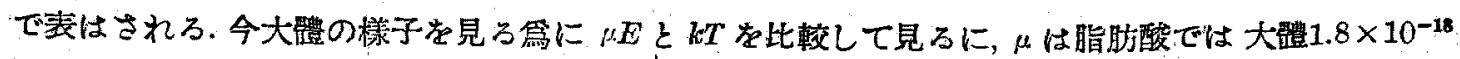
静電單位であり，Eに本惯驗に於け万最大の值 $50 \mathrm{KV}$ 郎ち 17 静電單位を入れっば

$$
\mu E / k t=0.007
$$

となり $\mu E$ は $k T$ に比し非常に小である.件し液體の粘度は其の內部構造に依つて非常に銳敏に左右 されろ故此の程度の電埸の大きさでも粘度に相當の影響な及ぼすと考人られろ. 双此の程度の電場で 恃だ能和點には遠い故電場の增加る共に粘度も增加すべきである。舅際ラウリン酸, ミリスチン酸 に於ては此の傾向が良く表はれてるるがン゚ルミチン酸では稍之に背離し，ステアリン酸に於ては就著 で電避か高くなると粘度の堿加率となる. 即ち分子量の大なる程背離は甚しい.セチルアルコールの

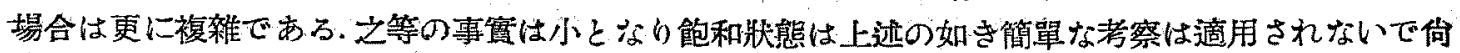
外に種々の因子が含まれると持へられる. 溶筫分子の會合等も事情花複雜にする一因子であると考 人られる.

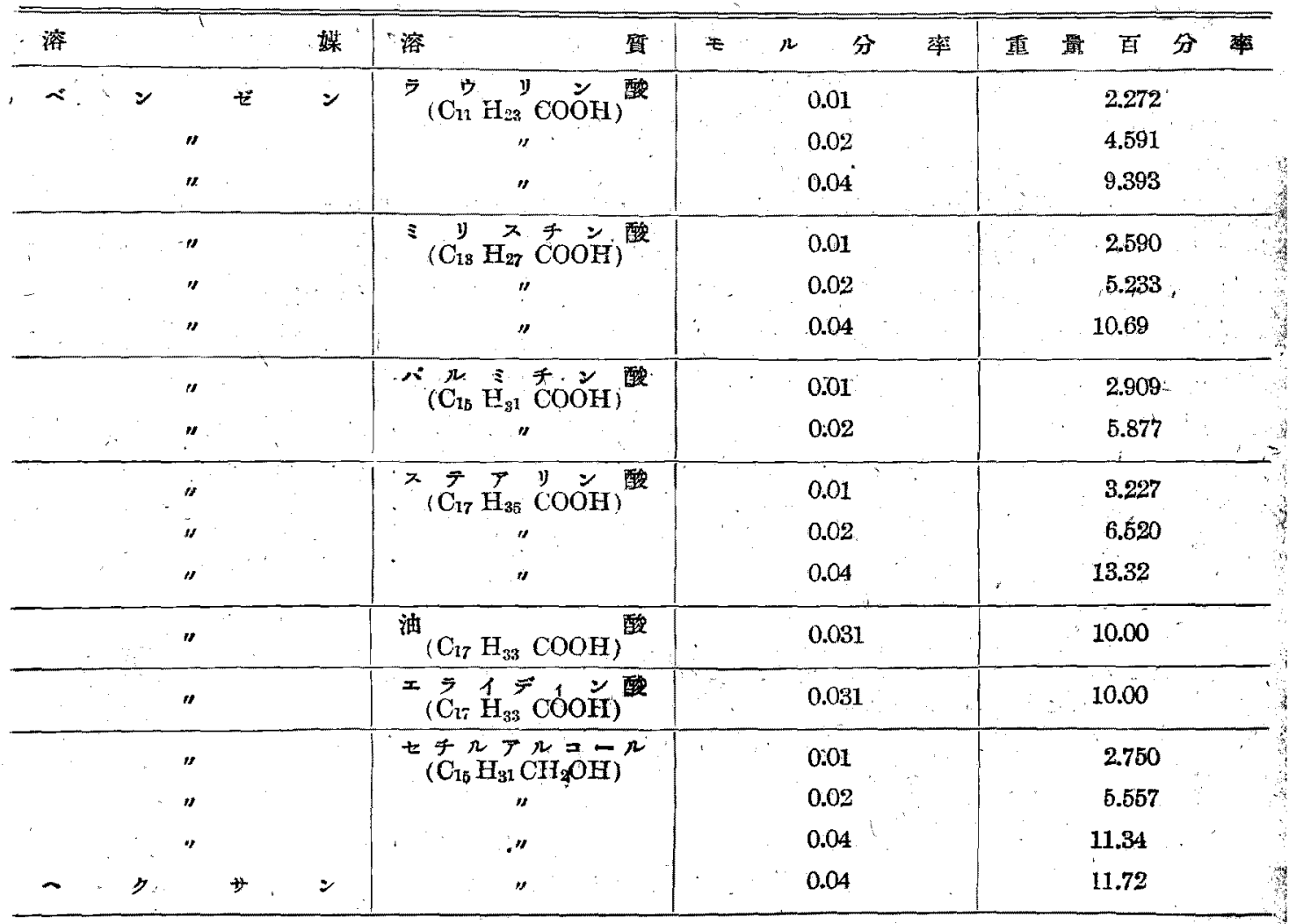

終りに臨み本研究に當り多大の御鞭样を與へられた佐多教授に對して感謝の意を表する. 